\title{
Multi-Warehouses Inventory Problem of Deteriorating Items with Fuzzy Lead-Time and Partial Lost Sales under Inflation and Time Value of Money
}

\author{
Jayanta Kumar Dey \\ Department of Mathematics, \\ Mahishada Raj College, \\ Purba-Midnapore, W.B - \\ 721628
}

\author{
Shyamal Kumar Mandal \\ Department of Applied \\ Mathematics, \\ Vidyasagar University, \\ Midnapore, \\ W.B.- 721102, India,
}

\author{
Manoranjan Maiti \\ Department of Applied \\ Mathematics, \\ Vidyasagar University, \\ Midnapore, \\ W.B.- 721102, India,
}

\begin{abstract}
In this paper, a realistic replenishment model with multiple warehouses (one is primary warehouse (PW) from where the items are sold and others are secondary warehouses (SWs) where the items are stored) is developed with fuzzy lead-time under the assumption that the capacities of the warehouses are finite. Inflation and time value of money are taken into account. The items of secondary warehouses are transported to the primary warehouse in continuous release pattern and associated transportation cost is proportional to the distance from PW to SWs. The holding cost of items in SWs has reverse effect with distance. Here, the demand of items is a deterministic function of selling price and the displayed inventory. Deterioration rates of the items are constant and different in different warehouses. The replenishment rate is infinite and the problem is constructed with shortages, which are the mixture of back orders and lost sales. The backlogged demand is assumed to be a function of currently backlogged amount. When an item is out of stock, the loyal and captive customers will wait until the outstanding orders arrive and are served. To compensate the inconvenience of backordering and to secure orders, the supplier may offer a price discount on the stock out item. There are three scenarios depending upon the time when the new order is placed for the next cycle. The problem is illustrated with the help of numerical examples.
\end{abstract}

\section{Keywords}

Inventory, Multi-warehouses, Deterioration, Fuzzy lead-time, Back order, Lost sale, Backorder discount, Inflation, Time value of money.

\section{INTRODUCTION}

In important markets like super market, corporation market, municipality market etc., the space for a showroom is limited. When an attractive price discount for balk purchase is available or the cost of procuring goods is higher than the inventory related other costs or the demand of items is very high, management then decides to purchase a large amount of items at a time. These large numbers of items may not be accommodated in the existing showroom (viz., the Primary Warehouse, PW) due to limited capacity. To store the excess items, one or more additional warehouses (viz., the Secondary Warehouses, SWs) are hired. These secondary warehouses may be located near PW or a little / far away from it. The items are stored first in PW and only excess stocks are stored in SW. The actual service to the customer is done at PW only. The items of SWs are transferred to PW in a continuous/bulk release pattern to meet up the demand at PW until the stock levels in SWs are emptied and lastly the items of PW are released. There are several related papers presented in this area such as Hartley [1], Sarma[2], Goswami and Chaudhuri[3], Pakkala Achary[4,5], Bhunia and Maiti[6] and others.

Many supermarket/corporation market managers have observed that for certain items, displayed stock level (DSL) has a positive impact on the demand rate. A large amount of stock generates high rate of consumption and consumption rate goes down when the stock level is low. Hence, it is concluded that there is a functional relationship between the demand of an item and its displayed stock level in a showroom / shop. This relationship was first considered by Levin et. al.[7] and then by Silver and Peterson[8], Backer and Urban[9], Mandal and Phauzdar[10], Datta and Pal[11,12] etc. According to real life situation, the demand rate is not only dependent on the stock level, it also depends on the selling price and it has a reverse effect.

A stock out occurs in the business of all types of items. During the stock out period, either all the demand is backordered, in which all customers wait until their demand is satisfied; or all the demand is lost. However, in many real inventory systems, demand can be captive partially. For customers whose needs are not urgent at that time can wait to be satisfied, while others who cannot wait will balk away to some other sources. The cost for a lost sale ranges from profit loss on the sale to some unspecifiable loss of good will. In order to compensate customers for the inconvenience of waiting, the idleness of equipment, or even lost production during the stock out period, the supplier may offer a variable price discount (Pan et. al $[14,15]$ ) on the stock out item depending on the seriousness of the back order condition.

From financial standpoint, an inventory represents a capital investment and must compete with other assets within the firm's limited capital funds. Most of the classical inventory models did not take into account the effects of inflation and time value of money. This has happened mostly because of the belief that inflation and time value of money will not influence the cost and price components i.e., the inventory control policy to any significant degree. But, during last few decades, due to high inflation and consequent sharp decline in the purchasing power of money in the developing countries like Brazil, Argentina, India, Bangladesh etc., the financial situation has been completely changed and so it is not possible to ignore the effect of inflation and time value of money any further. Following Buzacott [16] and Misra [17], several researchers (Ray and Chaudhuri [18], Sarkar et.al [19] etc.) have extended their approaches to different inventory models by considering the time value of money, different inflation 
rates for the internal and external costs, finite replenishment, shortages, etc.

In this paper, we consider one Primary Warehouse (PW), $\mathrm{m}$ secondary warehouses (viz., $\mathrm{SW}_{1}, \mathrm{SW}_{2}, \ldots . ., \mathrm{SW}_{\mathrm{m}}$ ) and $\mathrm{N}$ items. The warehouses $\mathrm{SW}_{1}, \mathrm{SW}_{2}, \ldots \ldots, \mathrm{SW}_{\mathrm{m}}$ contains $\mathrm{N}_{1}, \mathrm{~N}_{2}, \ldots, \mathrm{N}_{\mathrm{m}}$ items respectively such that $\mathrm{N}_{1}+\mathrm{N}_{2}+\ldots+\mathrm{N}_{\mathrm{m}}=$ $\mathrm{N}$. Items are sold from PW which is located at main market and shortages are allowed at this shop. Due to large stock and insufficient space of existing PW, excess items are stored in $\mathrm{m}$ secondary warehouses (viz., $\mathrm{SW}_{1}, \mathrm{SW}_{2}, \ldots . ., \mathrm{SW}_{\mathrm{m}}$ ) of finite capacity which are far away from PW. Here all the warehouses are of rental basis but rent of PW is greater than the rent of the secondary warehouses as they (SW's) are in far away from market place. Deterioration rate of an item is taken to be different in different warehouses. The stocks of SW's are transferred to PW under continuous release pattern and the associated transportation cost is directly varies with the distance from PW to SWs but the holding cost of an item in SWs has reverse effect with distance. In realistic retail situations, some customers wait for backlogged items in stock-out period and hence lost sale occurs. The backlogged demand is assumed to be a function of currently backlogged amount. Here, the problem is developed with fuzzy lead-time under inflation and time value of money. The fuzzy parameter is transformed into a crisp number by Graded Mean Integration Value(GMIV) method (Chen et. al.[13],). There are three scenarios in each cycle depending upon the time when new order is placed:

Scenario-I: New order is placed at the time before exhaustion of the inventory level of $\mathrm{SWj}$.

Scenario-II: New order is placed at the time when inventory level of SWj reaches zero.

Scenario-III: New order is placed when inventory level is only at PW.

Numerical examples are used to illustrate each scenario via genetic algorithm. Block diagram of the model is given below:

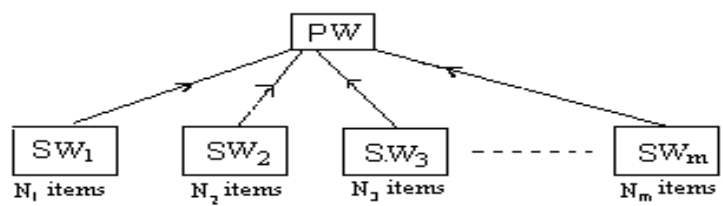

\section{ASSUMPTIONS AND NOTATIONS}

The inventory model with fuzzy lead-time is developed under the following assumptions and notations:

\section{Assumptions:}

(i) Rate of replenishment is infinite and the replenishment size is finite.

(ii) The inventory-planning horizon is infinite and the inventory system involves $\mathrm{n}$ items.

(iii) Shortages are allowed in PW and backlogged them fully.

(iv) There is no quantity discount.

(v) The units will be sold from primary warehouse (PW) and the space in PW will be immediately filled up by shifting same

amount from secondary warehouses (SW's) to PW. (vi) Time tag between selling from PW and filling up its space by new units from SW's is negligible.

(vii) Wavy bar ' $\sim$ 'represents the fuzzification of the parameter.

\section{Notations:}

For $i$-th items $(\mathrm{i}=1,2, \ldots, \mathrm{N})$ and $\mathrm{j}$-th secondary warehouse $(\mathrm{j}=1,2, \ldots, \mathrm{m})$

(i) $\quad \mathrm{S}_{\mathrm{i}}=$ Total stock of the system at $\mathrm{t}=0$.

(ii) $\quad \mathrm{W}_{\mathrm{i}}=$ Inventory of i-th item at PW.

(iii) $\quad \mathrm{W}_{\mathrm{i}}=$ On hand inventory of the system for i-th item when the new order is placed for the next cycle.

(iv) $\quad \mathrm{R}_{\mathrm{i}}=$ Shortage amount for $\mathrm{i}$-th item.

(v) $\quad t_{1 i}=$ Time when new order is placed for the next consignment.

(vi) $\quad t_{2 i}=$ Time when inventory level of $\mathrm{SW}_{\mathrm{j}}$ is zero

(vii) $\quad t_{3 i}=$ Time when inventory level of $\mathrm{PW}$ is zero i.e., when shortage begins.

(viii) $\quad \mathrm{t}_{4 \mathrm{i}}=$ Total time period for the cycle

(ix) $\quad C_{1 i}^{\mathrm{P}}=$ The inventory carrying cost per unit per unit time in PW.

$\mathrm{d}_{\mathrm{j}}=$ Distance of $\mathrm{SW}_{\mathrm{j}}$ from PW.

$C_{1 i}^{\mathrm{Swj}}=C_{1 i}^{\mathrm{P}}-\mathrm{c}^{\prime} \mathrm{d}_{\mathrm{j}}=$ The inventory carrying cost per unit per unit time in $\mathrm{SW}_{\mathrm{j}}$.

$C_{2 i}=$ Shortage cost per unit per unit time.

$\mathrm{C}_{3 \mathrm{i}}=$ Replenishment cost per cycle.

$\tilde{L}_{i}=$ Imprecise lead-time for the i-th item, where $\tilde{\mathrm{L}}_{\mathrm{i}}=\left(\mathrm{L}_{1 \mathrm{i}}, \mathrm{L}_{2 \mathrm{i}}, \mathrm{L}_{3 \mathrm{i}}\right)$ is parabolic or triangular fuzzy number.

$q_{1 i}(t)=$ Inventory level of secondary warehouses $\left(\mathrm{SW}_{\mathrm{j}}\right)$ at any time $\mathrm{t}$.

$q_{2 i}(t)=$ Inventory level of primary warehouse (PW) at any time t.

(xvii) $\quad \mathrm{f}\left(\mathrm{p}_{\mathrm{i}}, \mathrm{q}_{\mathrm{i}}\right)=\alpha_{\mathrm{i}}-\beta_{\mathrm{i}} \mathrm{p}_{\mathrm{i}}+\gamma_{\mathrm{i}} \mathrm{q}_{\mathrm{i}}(\mathrm{t}), \quad$ where $\mathrm{q}_{\mathrm{i}}(\mathrm{t})$ is the inventory level at any time $\mathrm{t}$.

(xviii) $\theta_{1 \mathrm{i}}=$ Constant deterioration rate for $\mathrm{i}$-th item in PW. 
(xix) $\theta_{2 \mathrm{i}}=$ Constant deterioration rate for $\mathrm{i}$-th item in $\mathrm{SW}_{\mathrm{j}}$.

$$
C_{p i}=C_{p i}^{\prime}-C_{p i}^{\prime \prime} S_{i}^{K_{1}}-C_{p i}^{\prime \prime} \quad L_{i}
$$

Purchasing cost per unit quantity depends upon the initial stock level $\mathrm{S}_{\mathrm{i}}$ and lead-time $\mathrm{L}_{\mathrm{i}}$ (

$$
\mathrm{C}_{\mathrm{pi}}^{\prime}, \mathrm{C}_{\mathrm{pi}}^{\prime \prime}, \mathrm{C}_{\mathrm{pi}}^{\prime \prime \prime}, \mathrm{K}_{1}, \mathrm{~K}_{2}>0 \text { ). }
$$

(xxi) $\quad \mathrm{p}_{\mathrm{i}}=K^{\prime} \cdot C_{p i}$, selling price per unit quantity in stock-in period.

(xxii) $\quad \pi_{\mathrm{di}}=$ Backorder price discount offered by the supplier per unit which is variable and lies between 0 and $\left(\mathrm{p}_{\mathrm{i}}-C_{p i}\right)$.

(xxiii) $\quad \mathrm{p}_{\mathrm{i}}^{\prime}=\mathrm{p}_{\mathrm{i}}-\pi_{\mathrm{di}}$, Selling price per unit quantity in stock-out period.

(xxiv) $T_{c i}=T_{c i}^{\prime}+T_{c i}^{\prime \prime} S_{R P i} d_{i}$, transportation cost for transporting $S_{R P i}$ units from $\mathrm{SW}_{\mathrm{j}}$ to $\mathrm{PW}$ ( $\mathrm{T}_{\mathrm{ci}}^{\prime}, \mathrm{T}_{\mathrm{ci}}^{\prime \prime}, \mathrm{k}>0$ ) where $\mathrm{T}_{\mathrm{ci}}^{\prime}$ is the fixed transportation cost and $\mathrm{T}_{\mathrm{ci}}^{\prime \prime}$ is the transportation cost per unit per unit distance.

(xxv) $\mathrm{R}=$ Difference between inflation rate and discount rate.

(xxvi) $\quad \mathrm{PW}_{\mathrm{C}}=$ Total capacity of PW.

(xxvii) $\quad \mathrm{SW}_{\mathrm{Cj}}=$ Capacity of $\mathrm{j}$-th secondary warehouse.

\section{MATHEMATICAL FORMULATION}

Pictorial representation of the scenarios is depicted as below:

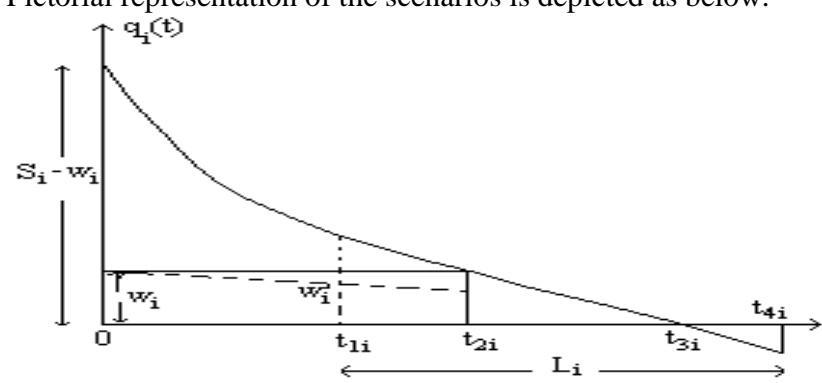

Fig-1: inventory situation in scenario-I
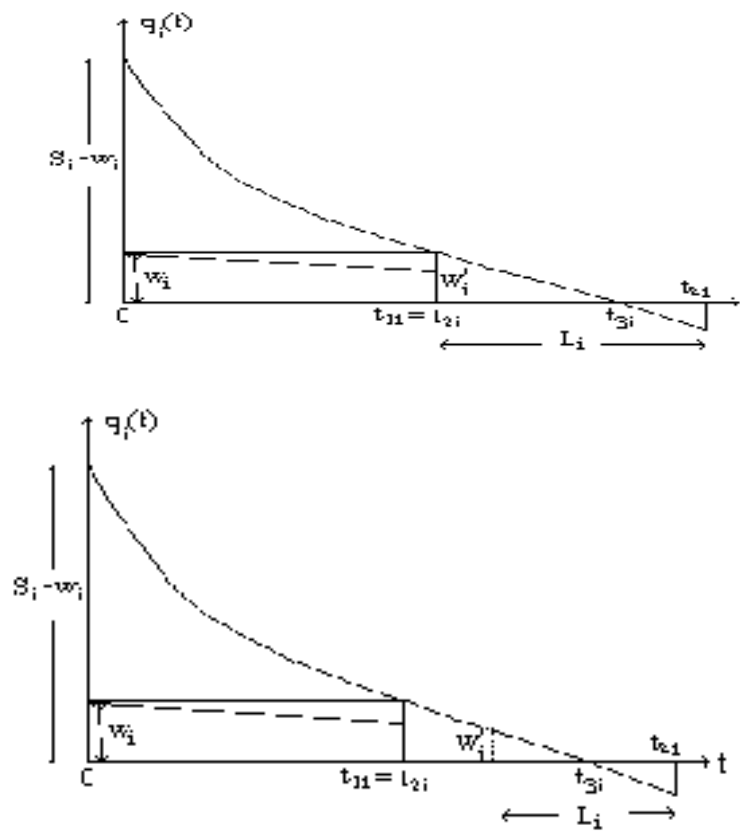

Fig-2: Inventory situation in scenario-II Fig-3: Inventory situation in scenario-III

\section{Formulation of scenario-I}

The deferential equation describing the inventory level $\mathrm{q}_{1 \mathrm{i}}(\mathrm{t})(\mathrm{i}=1,2, \ldots, \mathrm{n})$ of the system is

$\frac{\mathrm{dq}_{1 \mathrm{i}}(\mathrm{t})}{\mathrm{dt}}=-\theta_{1 \mathrm{i}} q_{1 \mathrm{i}}(\mathrm{t})-\mathrm{D}_{\mathrm{i}}-\theta_{2 \mathrm{i}} \mathrm{w}_{\mathrm{i}}, \quad 0 \leq t \leq t_{2 i}$

with boundary conditions:

$$
\begin{aligned}
& q_{1 \mathrm{i}}(t)=S_{i}-w_{i} \quad \text { at } \quad t=0 \\
& =w_{i}^{\prime}-w_{i} \quad \text { at } \quad t=t_{1 i} \\
& =0 \quad \text { at } \quad t=t_{2 i} \\
& =-R_{i} \quad \text { at } \quad t=t_{4 i}
\end{aligned}
$$

The deferential equation describing the inventory level $\mathrm{q}_{2 \mathrm{i}}(\mathrm{t})(\mathrm{i}=1,2, \ldots, \mathrm{n})$ of the system is

$$
\frac{\mathrm{dq}_{2 \mathrm{i}}}{\mathrm{dt}}=\left\{\begin{array}{lc}
-\left(\theta_{2 i} \mathrm{q}_{2 \mathrm{i}}+D_{i}\right), & t_{2 i} \leq t \leq t_{3 i} \\
-\left(D_{i}+\delta_{i} \mathrm{q}_{2 \mathrm{i}}\right), & t_{3 i} \leq t \leq t_{4 i}
\end{array}\right.
$$

where $\delta_{\mathrm{i}}=\frac{\delta_{0}}{\pi_{d i}}\left(\delta_{0}>0\right)$ and boundary conditions are:

$$
\begin{aligned}
& q_{2 i}(t)=w_{i} \quad \text { at } \quad t=t_{2 i} \\
& =0 \quad \text { at } \quad t=t_{3 i} \\
& =-R_{i} \quad \text { at } \quad t=t_{4 i}
\end{aligned}
$$

(4) 
where

$$
D_{i}= \begin{cases}f\left(p_{i}, w_{i}\right), & q_{i} \geq w_{i} \\ f\left(p_{i}, q_{i}\right), & 0 \leq q_{i} \leq w_{i} \\ f\left(p_{i}, 0\right), & q_{i}<0\end{cases}
$$

Using (2), the solution of the differential equation (1) is given by

$\mathrm{q}_{1 \mathrm{i}}(\mathrm{t})=\frac{1}{\theta_{1 \mathrm{i}}}\left\{f\left(p_{i}, w_{i}\right)+\theta_{2 \mathrm{i}} \mathrm{w}_{\mathrm{i}}\right\}\left\{e^{\theta_{1 \mathrm{i}}\left(t_{2 i}-t\right)}-1\right\}$

Using (4), the solution of the differential equation (3) is given by

$$
q_{2 i}(t)=\left\{\begin{array}{l}
\frac{\left(\alpha_{\mathrm{i}}-\beta_{\mathrm{i}} \mathrm{p}_{\mathrm{i}}\right)}{\gamma_{\mathrm{i}}+\theta_{2 \mathrm{i}}}\left\{\mathrm{e}^{\left(\gamma_{\mathrm{i}}+\theta_{2 \mathrm{i}}\right)\left(\mathrm{t}_{3 \mathrm{i}} \mathrm{t}\right)}-1\right\}, \\
\frac{\mathrm{D}_{\mathrm{i}}}{\delta_{\mathrm{i}}}\left\{\mathrm{e}^{\delta_{\mathrm{i}}\left(\mathrm{t}_{3 \mathrm{i}}-\mathrm{t}\right)}-1\right\},
\end{array}\right.
$$

Using (2) and (4), equations (5) and (6) give

$$
\begin{aligned}
& S_{i}=w_{i}+\frac{1}{\theta_{1 i}}\left\{f\left(p_{i}, w_{i}\right)+\theta_{2 i} w_{i}\right\}\left\{e^{\theta_{1 i} t_{2 i}}-1\right\} \\
& =w_{i}+\frac{1}{\theta_{1 i}}\left\{\alpha_{i}-\beta_{i} p_{i}+\left(\gamma_{i}+\theta_{2 i}\right) w_{i}\right\}\left\{e^{\theta_{1 i} t_{2 i}}-1\right\}
\end{aligned}
$$

$w_{i}^{\prime}=w_{i}+\frac{1}{\theta_{1 i}}\left\{f\left(p_{i}, w_{i}\right)+\theta_{2 i} w_{i}\right\}\left\{e^{\theta_{1 i}\left(t_{2 i}-t_{1 i}\right)}-1\right\}$

$=w_{i}+\frac{1}{\theta_{1 i}}\left\{\alpha_{i}-\beta_{i} p_{i}+\left(\gamma_{i}+\theta_{2 i}\right) w_{i}\right\}\left\{e^{\theta_{1 i}\left(t_{2 i}-t_{1 i}\right)}-1\right\}$

(9)

$$
\tilde{R}_{i}=\frac{D_{i}}{\delta}\left\{1-\left(1-\delta \tilde{L}_{i}\right) e^{\delta\left(t_{3 i}-t_{1 i}\right)}\right\}
$$

(10)

$$
\begin{aligned}
& t_{1 i}=\int_{w_{i}^{\prime}-w_{i}}^{S_{i}-w_{i}} \frac{d q_{1 i}}{\theta_{1 i} q_{1 i}(t)+f\left(p_{i}, q_{i}\right)+\theta_{2 i} w_{i}} \\
& =\frac{1}{\theta_{1 i}} \log \left|\frac{\alpha_{i}-\beta_{i} p_{i}+\left(\gamma_{i}+\theta_{2 i}-\theta_{1 i}\right) w_{i}+\theta_{1 i} S_{i}}{\alpha_{i}-\beta_{i} p_{i}+\left(\gamma_{i}+\theta_{2 i}-\theta_{1 i}\right) w_{i}+\theta_{1 i} w_{i}^{\prime}}\right|
\end{aligned}
$$

$$
\begin{aligned}
& t_{2 i}=\int_{0}^{S_{i}-w_{i}} \frac{d q_{1 i}}{\theta_{1 i} q_{1 i}(t)+f\left(p_{i}, q_{i}\right)+\theta_{2 i} w_{i}} \\
& =\frac{1}{\theta_{1 i}} \log \left|\frac{\alpha_{i}-\beta_{i} p_{i}+\left(\gamma_{i}+\theta_{2 i}-\theta_{1 i}\right) w_{i}+\theta_{1 i} S_{i}}{\alpha_{i}-\beta_{i} p_{i}+\left(\gamma_{i}+\theta_{2 i}\right) w_{i}}\right|
\end{aligned}
$$

$t_{3 i}=t_{2 i}+\int_{0}^{w_{i}} \frac{d q_{2 i}}{\theta_{2 i} q_{2 i}(t)+f\left(p_{i}, q_{i}\right)}$

$$
=\frac{1}{\gamma_{i}+\theta_{2 i}} \log \left|\frac{\alpha_{i}-\beta_{i} p_{i}+\left(\gamma_{i}+\theta_{2 i}\right) w_{i}}{\alpha_{i}-\beta_{i} p_{i}}\right|
$$

$$
t_{3 i} \leq t \leq \underset{\mathrm{j}-\mathrm{th} \text { Secondary Warehouse }\left(\mathrm{SW}_{\mathrm{j}}\right)}{\mathrm{C}_{4}^{\mathrm{Hi}}} \mathrm{Swj} \text { Present value of holding cost for the i-th item in the }
$$

$$
=\mathrm{C}_{1 \mathrm{i}}^{\mathrm{swj}} \int_{0}^{t_{2 i}} q_{1 i}(t) e^{-R t} d t
$$$$
=\frac{C_{1 \mathrm{i}}^{\text {Swj }}}{\theta_{\mathrm{li}}}\left\{\alpha_{i}-\beta_{i} p_{i}+\left(\gamma_{i}+\theta_{2 i}\right) w_{i}\right\}\left[\frac{1}{\theta_{1 i}+R}\left(e^{\theta_{1 i} t_{2 i}}-e^{-R t_{2 i}}\right)-\frac{1}{R}\left(1-e^{-R t_{2 i}}\right)\right]
$$

$\mathrm{C}_{\mathrm{Hi}}^{\mathrm{P}}=$ Present value of holding cost for the $\mathrm{i}$-th item in the Primary Warehouse (PW)

$$
=\mathrm{C}_{1 \mathrm{i}}^{\mathrm{P}}\left[\int_{0}^{t_{2 i}} w_{i} e^{-R t} d t+\int_{t_{2 i}}^{t_{3 i}} q_{2 i}(t) e^{-R t} d t\right]
$$

$$
=C_{1 \mathrm{i}}^{\mathrm{P}}\left[\frac{\mathrm{W}_{\mathrm{i}}}{\mathrm{R}}\left(1-\mathrm{e}^{-\mathrm{R} t_{2 \mathrm{i}}}\right)+\frac{\alpha_{\mathrm{i}}-\beta_{\mathrm{i}} \mathrm{p}_{\mathrm{i}}}{\left(\gamma_{\mathrm{i}}+\theta_{2 \mathrm{i}}\right)^{2}+\mathrm{R}\left(\gamma_{\mathrm{i}}+\theta_{2 \mathrm{i}}\right)} \mathrm{e}^{\left(\gamma_{\mathrm{i}}+\theta_{2 \mathrm{i}}\right) t_{3 \mathrm{i}}}\left\{\mathrm{e}^{-\left(\gamma_{\mathrm{i}}+\theta_{2 \mathrm{i}}+\mathrm{R}\right) t_{2 \mathrm{i}}}-\mathrm{e}^{-\left(\gamma_{\mathrm{i}}+\theta_{2 \mathrm{i}}+\mathrm{R}\right) t_{3 i}}\right\}\right.
$$$$
\left.-\frac{\alpha_{i}-\beta_{i} p_{i}}{R\left(\gamma_{i}+\theta_{2 i}\right)}\left(e^{-R t_{3 i}}-e^{-R t_{2 i}}\right)\right]
$$

$C_{D i}=$ Present value of the cost for the total deteriorated i-th item during $\left(0, \mathrm{t}_{3 \mathrm{i}}\right)$ 


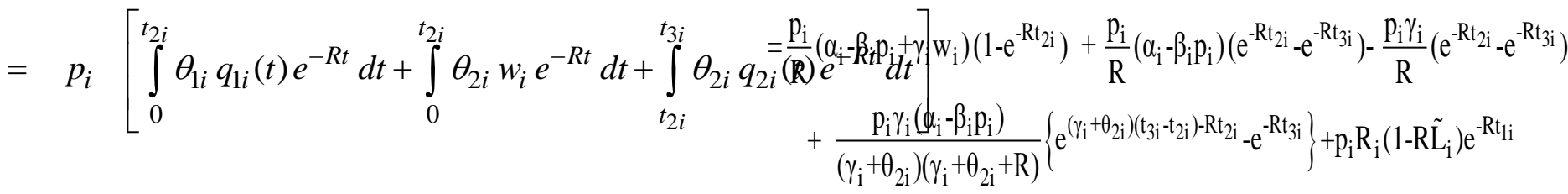

$$
\begin{aligned}
& =\frac{\mathrm{p}_{\mathrm{i}} \theta_{2 \mathrm{i}} \mathrm{C}_{\mathrm{Hi}}^{\mathrm{Swj}}}{\mathrm{C}_{1 \mathrm{i}}^{\mathrm{Swj}}}+\frac{\mathrm{p}_{\mathrm{i}} \theta_{2 \mathrm{i}} \mathrm{C}_{\mathrm{Hi}}^{\mathrm{P}}}{\mathrm{C}_{1 \mathrm{i}}^{\mathrm{P}}} \\
& =T C_{i}^{\prime}+S_{R P i} d_{j} T C_{i}^{\prime \prime}, \quad j=1,2, \ldots ., m
\end{aligned}
$$

$S_{R P i}=$ Total units of i-th item transferred from $S W_{j}$ 's to PW

$$
=\left(\mathrm{S}_{\mathrm{i}}-\mathrm{w}_{\mathrm{i}}\right)-\int_{0}^{\mathrm{t}_{2 \mathrm{i}}} \theta_{1 \mathrm{i}} \mathrm{q}_{1 \mathrm{i}}(\mathrm{t}) \mathrm{dt}
$$

$=\left(\mathrm{S}_{\mathrm{i}}-\mathrm{w}_{\mathrm{i}}\right)-\left\{\alpha_{\mathrm{i}}-\beta_{\mathrm{i}} \mathrm{p}_{\mathrm{i}}+\left(\gamma_{\mathrm{i}}+\theta_{\mathrm{i}}\right) \mathrm{w}_{\mathrm{i}}\right\}\left\{\frac{1}{\theta_{1 \mathrm{i}}}\left(\mathrm{e}^{\theta_{1 \mathrm{i}} \mathrm{t}_{1 \mathrm{i}}}-1\right)-\mathrm{t}_{2 \mathrm{i}}\right\}$

$\tilde{\mathrm{C}}_{\mathrm{Si}}=$ Present value of Shortage cost during $\left(\mathrm{t}_{3 \mathrm{i}}, \mathrm{t}_{4 \mathrm{i}}\right)$

$=-C_{2 i} \int_{t_{3 i}}^{t_{4 i}} q_{2 i}(t) e^{-R t} d t$

where $\quad \mathrm{TC}_{\mathrm{i}}^{\prime}=$ Fixed transportation cost for the $\mathrm{i}$-th item and $\quad T C_{i}^{\prime \prime}=$ Transportation cost per unit per unit distance.

The profit function for the i-th item is given by

$\mathrm{PROF}_{\mathrm{i}=}$ Average profit for the $\mathrm{i}$-th item during $\left(0, t_{4 i}\right)$

$$
\tilde{\mathrm{S}}_{p i}-\tilde{P}_{c i}-C_{d i}-C_{H i}^{S w j}-C_{H i}^{P}-\tilde{C}_{S i}-C_{3 i}-T C_{i}^{j}
$$

) $/ t_{4 i}$

Total profit for $\mathrm{N}$-items is

$$
\text { PROF } \quad=\sum_{i=1}^{N} \text { PROF }_{i}
$$

Our problem is to Maximize PROF

$$
=\frac{\mathrm{C}_{2 \mathrm{i}} \mathrm{D}_{\mathrm{i}}}{\left(\mathrm{R}+\delta_{\mathrm{i}}\right) \delta_{\mathrm{i}}}\left[\left\{1-\left(\mathrm{R}+\delta_{\mathrm{i}}\right) \tilde{\mathrm{L}}_{\mathrm{i}}\right\} \mathrm{e}^{-\mathrm{Rt}_{1 \mathrm{i}}+\delta_{\mathrm{i}}\left(\mathrm{t}_{3 \mathrm{i}}-\mathrm{t}_{1 \mathrm{i}}\right)}-\mathrm{e}^{-\mathrm{Rt} \mathrm{t}_{3 \mathrm{i}}}\right]-\frac{\mathrm{C}_{2 \mathrm{i}} \mathrm{D}_{\mathrm{i}}}{\mathrm{R} \delta_{\mathrm{i}}}\left[\left(1-\mathrm{R}_{\mathrm{b}} \tilde{f}_{\mathrm{e}}\right) \mathrm{e}_{\mathrm{to}}^{-\mathrm{Rt}_{1 \mathrm{i}}}-\mathrm{e}^{-\mathrm{R}^{N} \sum_{i=1}^{N}} a_{i} w_{i} \leq \quad O W\right.
$$

$\tilde{\mathrm{P}}_{c i}=$ Present value of total purchasing cost for the i-th item during $\left(0, t_{4 i}\right)$

$$
=C_{p i}\left\{S_{i}+R_{i}\left(1-R \tilde{L}_{i}\right) e^{-R t_{1 i}}\right\}
$$

$\tilde{\mathrm{P}}_{\mathrm{i}}=$ Selling price for the $\mathrm{i}-$ th item $=\mathrm{K}_{4} \tilde{\mathrm{C}}_{\mathrm{Pi}}$ (20)

$\tilde{S}_{\mathrm{pi}}=$ Present value of total sales for the i-th item during $\left(0, t_{4 i}\right)$

$$
=p_{i} \int_{0}^{t_{3 i}} D_{i} e^{-R t} d t+p_{i} R_{i} e^{-R \tilde{t}_{4 i}}
$$

\section{GRADED MEAN INTEGRATION} VALUE (GMIV) OF A FUZZY NUMBER Let $A$ be a fuzzy number with membership function $\mu_{\tilde{\mathrm{A}}}(\mathrm{X})$ as given below:

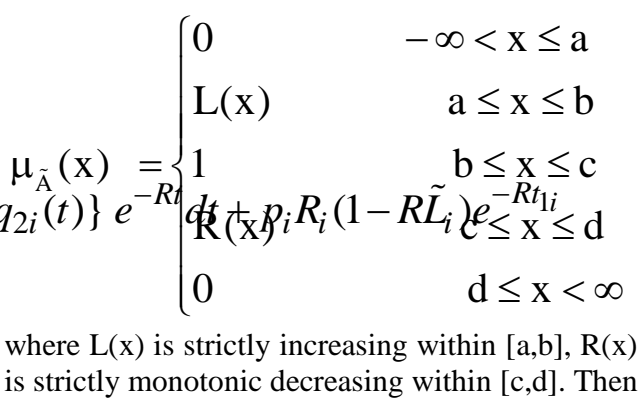

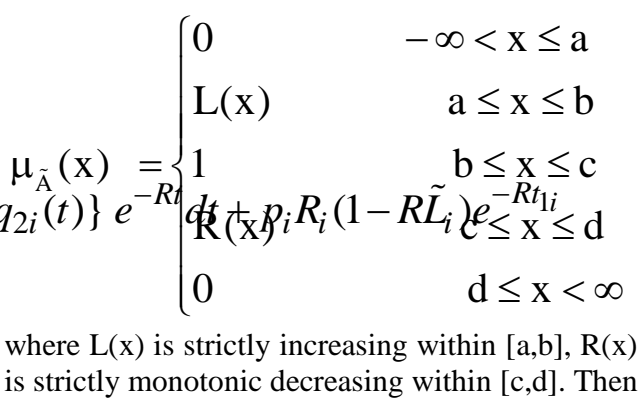

$T C_{i}^{j}=$ Transportation cost for transporting $S_{R P i}$ units from $\mathrm{SW}_{\mathrm{j}}$ to $\mathrm{PW}$ 
according to Chen and Hsien (1999), GMIV of $\tilde{\mathrm{A}}$ is denoted by $\mathrm{P}(\tilde{\mathrm{A}})$ and defined as:

$$
\mathrm{P}(\tilde{\mathrm{A}})
$$

$$
\frac{\int_{0}^{1} x\left\{w L^{-1}(x)+(1-w) R^{-1}(x)\right\} d x}{\int_{0}^{1} x d x}=
$$

$$
2 \int_{0}^{1} \mathrm{x}\left\{\mathrm{w} \mathrm{L}^{-1}(\mathrm{x})+(1-\mathrm{w}) \mathrm{R}^{-1}(\mathrm{x})\right\} \mathrm{dx}
$$

Where $\mathrm{W} \in[0,1]$ a pre-assigned parameter is called degree of optimism. $\mathrm{w}=1$ represents an optimistic viewpoint, $\mathrm{w}=0$ represents a pessimistic viewpoint and $\mathrm{w}=0.5$ reflects a moderately optimistic DM's view point. Using this rule GMIV of different type of fuzzy number is obtained and present in Table-1.

Table-1: GMIV formula for different fuzzy numbers with degree of optimism $w$

\begin{tabular}{|l|l|}
\hline $\begin{array}{l}\text { Triangular fuzzy number(TFN) } \\
(\mathrm{a}, \mathrm{b}, \mathrm{c})\end{array}$ & $\begin{array}{l}\text { Trapezoidal fuzzy number(TrFN) } \\
(\mathrm{a}, \mathrm{b}, \mathrm{c}, \mathrm{d})\end{array}$ \\
\hline$[\mathrm{wa}+2 \mathrm{~b}+(1-\mathrm{w}) \mathrm{c}] / 3$ & {$[\mathrm{w}(\mathrm{a}+2 \mathrm{~b})+(1-\mathrm{w})(\mathrm{d}+2 \mathrm{c})] / 3$} \\
\hline
\end{tabular}

\section{GENETIC ALGORITHM}

A genetic algorithm is a heuristic search process for optimization that resembles natural selection. Gas was first proposed by J. Holland. It has been applied successfully in different areas (Davis[20]). As the name suggests, GA originated from the analogy of biological evolution. GAs considers a population is a set of feasible solutions of a problem. A member of the population is called a genotype, a chromosome, a string or a permutation. A genetic algorithm contains three operators-reproduction, crossover and mutation. Initially, a population is selected and by means of above operators, the better of the population will remain, because of the survival of the fittest. The GAs procedure is shown below:

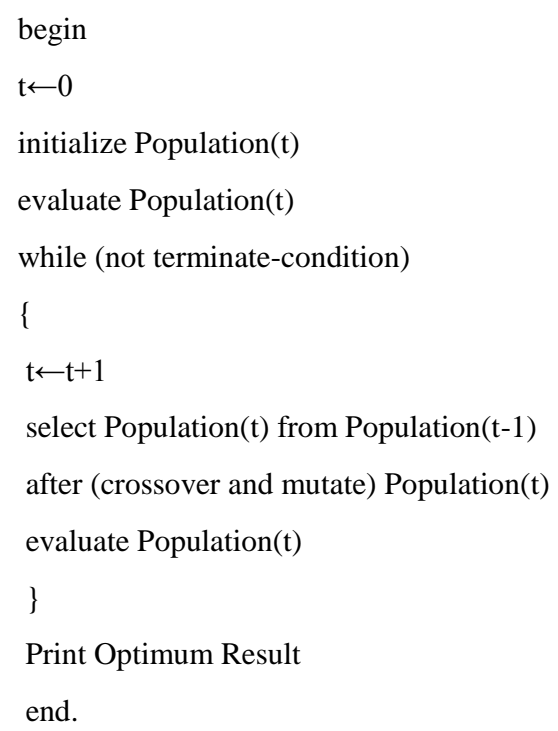

\section{Implementing GA}

It is generally accepted that a GA to solve a decision-making problem must have five basic components:

(i) values for the parameters (population size, probabilities of applying genetic operators, etc.)

(ii) a genetic representation for potential solutions,

(iii) a way to create an initial population of solutions,

(iv) an evaluation function (i.e., the environment), rating solutions in terms of their "fitness", and

(v) genetic operators that after the genetic composition of parents during reproduction.

We discuss these components for the system developed for the present model in the following sections.

\section{Parameters:}

Firstly, we set the different parameters on which this GA depends. These are the number of generations (MAXGEN), population size (POPSIZE), probability of crossover (PXOVER), probability of mutation (PMU). There is no clear indication as to how large a population should be. If the population is to large, there may be difficulty in storing the data, but if the population is too small, there may not be enough string for good crossovers. In our experiment, a population consists of 50 members i.e.,

POPSIZE $=50$. In this case, PXOVER $=0.2$, PMU $=0.2$, MAXGEN=5000.

\section{Chromosome representation:}

An important issue in applying a GA is to design an appropriate chromosome representation of solutions of the problem together with genetic operators. Traditional binary vectors used to represent the chromosome are not effective in many highly non-linear physical problems. Since the proposed problem is highly non-linear, hence to overcome the difficulty, a real number representation is used. In this representation, each chromosome $V_{i}$ consists of the genes $\mathrm{G}_{\mathrm{iw}_{\mathrm{j}}}, \mathrm{G}_{\mathrm{iS}_{\mathrm{j}}}$ and $\mathrm{G}_{\mathrm{iw}_{\mathrm{j}}^{\prime}}$ where these genes respectively denote decision variables $\mathrm{w}_{\mathrm{i}}, \mathrm{S}_{\mathrm{i}}$ and $\mathrm{w}_{\mathrm{i}}^{\prime}$ i.e.,

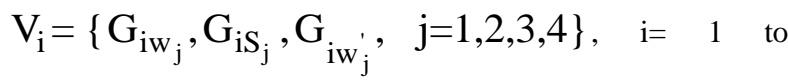
POPSIZE.

\section{Initial population:}

To initialize the population, we first determine the independent and dependent variables and then their boundaries. For each chromosome Vi, the gene Giwj which is independent, is randomly generated between its boundaries $\left(\mathrm{LB}_{\mathrm{K}}, \mathrm{UB}_{\mathrm{K}}\right)$ where $\mathrm{LB}_{\mathrm{K}}$ and $\mathrm{UB}_{\mathrm{K}}$ are the lower and upper bounds of the decision variable and after that other genes are also generated randomly betweens its boundaries until it is feasible by the following algorithm.

Step-I: $\quad G_{i w_{j}}=\operatorname{Rand}\left(0, \frac{O W}{a_{j}}\right), j=1$ to 4

Step-II: $\quad G_{i_{j}}=\operatorname{Rand}\left(G_{i w_{j}}, \frac{R W_{1}}{a_{j}}\right), j=1,2$

$$
\text { and } \mathrm{G}_{\mathrm{iS}_{\mathrm{j}}}=\operatorname{Rand}\left(\mathrm{G}_{\mathrm{iw}}, \frac{\mathrm{RW}_{2}}{\mathrm{a}_{\mathrm{j}}}\right), \mathrm{j}=3,4
$$


Step-III: $G_{i w_{j}^{\prime}}=\left\{\begin{array}{l}\operatorname{Rand}\left(G_{i w_{j}}, G_{i S_{j}}\right), j=1 \text { to } 4 \text { for scenario-I } \\ \operatorname{Rand}\left(0, G_{i_{j}}\right), \quad j=1 \text { to } 4 \text { for scenario-III }\end{array}\right.$

Step-IV: If all constraints are not satisfied by $\mathrm{V}_{\mathrm{i}}$ then go to step-I

\section{Evaluation:}

Evaluation function plays the same role in GA as that which the environment plays in natural evaluation. To this problem, the evaluation function is EVAL $(\mathrm{Vi})=$ objective function value.

\section{Selection:}

Before selection process, all chromosomes VI are arranged in descending order according to eval(Vi). After that the roulette wheel selection process is applied on it POPSIZE times. Each time we select a single chromosome for the new population in the following way:

(a) Calculate the fitness value eval(Vi) for each chromosome $\mathrm{Vi}$

(b) Find Total fitness of the population $\sum_{i=1}^{\text {popsize }} \operatorname{eval}\left(V_{I}\right)$

(c) Calculate the probality of selection, $\mathrm{p}_{\mathrm{I}}=\mathrm{eval}(\mathrm{vi}) / \mathrm{F}$ for each chromosome $\mathrm{Vi}$

(d) Calculate the cumulative probability $\mathrm{q}_{\mathrm{i}}$ for each chromosome $\mathrm{Vi}: q_{i}=\sum_{i=1}^{j} P_{j}$

(e) Generate a random real number $r$ in $(0,1)$.

(f) If $\mathrm{r}<\mathrm{q}_{\mathrm{i}}$ then the first chromosome is Vi otherwise select the $i$-th chromosome Vi $(2 \leq \mathrm{i} \leq$ POPSIZE $)$ such that $\mathrm{q}_{\mathrm{i}-1} \leq \mathrm{i} \leq \mathrm{q}_{\mathrm{i}}$.

(g) Repeat steps (e)and (f) POPSIZE times and obtain POPSIZE copies of chromosomes.

By this process, better chromosomes may be selected several times depending upon the generated random numbers.

\section{Crossover operations:}

The exploration and exploitation of the solution space is made possible by exchanging genetic information of the current chromosomes. Crossover operates on two parrent solutions at a time and generate ofspring solutions by recombining both parent solution features. After selection of chromosomes for new population, the crossover operation is applied. Here, the whole arithmetic crossover operation is used. It is done in the following way:

(a) Firstly, we generate a random real number, $r$ in $(0,1)$.

(b) Secondly, we select two chromosomes VK and Vi randomly among population for crossover if $r<$ PXOVR.

(c) Then two offsprings ' $V k$ and ' $V i$ are produced as follows: $V_{k}=c * V_{k}+(1-c) * V_{i}$

$V_{i}^{\prime}=c * V_{i}+(1-c) * V_{k}$ where $\mathrm{c} \in[0,1]$.

(d) Repeat the steps (a), (b) and (c) POPSIZE / 2 times.

In this problem crossovers are performed only on the gene which corresponds the variable wi for $i=1$ to 4 and other genes are genereted randomly betwwen its boundaries. If new chromosome satifies all the contraints then OK otherwise the previous values of the genes of the respective chromosomes are retained.

\section{Mutation operation:}

Mutation operation is used to prevent the search process from converging to local optima rapidly. Unlike crossover, it is applied to a single chromosome $V i$. Here, the mutation operation is defind as follows: (a) Firstly, we generate a random real number $\mathrm{r}$ in $(0,1)$.

(b) Secondly, we select a chromosome $V_{i}$ randomly from population if $\mathrm{r}<\mathrm{PMU}$.

(c) Thirdly, we select one gene $\mathrm{G}_{\mathrm{iw}_{\mathrm{j}}}$ among $\mathrm{G}_{\mathrm{iwk}}$, $\mathrm{k}=1$ to 4 , of the selected chromosome $V i$ randomly.

(d) Then the new gene $G_{i w j}^{m u i}$ of $\mathrm{G}_{\mathrm{iw}_{\mathrm{j}}}$ due to mutation is produced in the following way: $G_{i w j}^{m u i}=\operatorname{Rand}\left(\mathrm{LB}_{\mathrm{K}}, \mathrm{UB}_{\mathrm{K}}\right)$

(e) Repeat the steps (a), (b), (c) and (d) POPSIZE times.

In this problem mutation is performed only on the gene which corresponds the variable $\mathrm{w}_{\mathrm{i}}$ for a randomly selected $\mathrm{i}$ among 0 and 4 and other corresponding genes are genereted randomly betwwen its boundaries. If new chromosome satisfies all the constraints then $\mathrm{OK}$ otherwise the previous values of the genes of the respective chromosomes are retained.

\section{Termination:}

If number of iteration is less than or equal to MAXGEN then the process is going on, otherwise it terminates.

\section{NUMERICAL ILLUSTRATION}

For numerical illustration, only four items and two rented warehouses are considered here. The non-linear programming problem (25) is solved by GA for the following numerical data shown in Tables-2a , $2 \mathrm{~b}$ and the optimal results are shown in Table-3 and Table-4, profit values are shown for different values of y (degree of optimism).

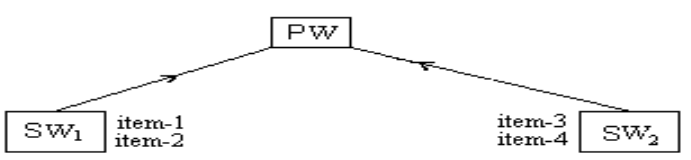

Table-2a: Parametric values

\begin{tabular}{|c|c|c|c|c|c|c|c|c|c|c|c|c|}
\hline $\begin{array}{l}\text { Ite } \\
\mathrm{m}\end{array}$ & $C_{1}^{\mathrm{B}}$ & $\mathrm{C}_{2}$ & $\mathrm{C}_{3}$ & $\alpha_{1}$ & $\beta_{1}$ & $\gamma_{1}$ & $\mathrm{C}_{\mathrm{H}}^{\prime}$ & $C^{\prime \prime}$ & $\mathrm{C}^{\prime \prime}$ & $\theta_{1}$ & $\theta_{2}$ & $\mathrm{a}_{\mathrm{i}}$ \\
\hline $\begin{array}{l}\text { It } \\
\mathrm{e} \\
\mathrm{m} \\
- \\
1\end{array}$ & $\begin{array}{l}1 . \\
4 \\
2\end{array}$ & $\begin{array}{l}2 . \\
8 \\
0\end{array}$ & $\begin{array}{l}4 \\
6 \\
0\end{array}$ & $\begin{array}{l}1 \\
5 \\
0\end{array}$ & $\begin{array}{l}0 . \\
6 \\
5\end{array}$ & $\begin{array}{l}0 . \\
3 \\
4\end{array}$ & $\begin{array}{l}70 \\
.0 \\
0\end{array}$ & $\begin{array}{l}0 . \\
03 \\
6\end{array}$ & $\begin{array}{l}0.0 \\
05 \\
0\end{array}$ & $\begin{array}{l}0 . \\
0 \\
1 \\
0\end{array}$ & $\begin{array}{l}0 . \\
0 \\
1 \\
1\end{array}$ & $\begin{array}{l}0 \\
. \\
4 \\
5\end{array}$ \\
\hline $\begin{array}{l}\text { It } \\
\mathrm{e} \\
\mathrm{m} \\
-\end{array}$ & $\begin{array}{l}1 . \\
4 \\
1\end{array}$ & $\begin{array}{l}2 . \\
8 \\
6\end{array}$ & $\begin{array}{l}4 \\
5 \\
5\end{array}$ & $\begin{array}{l}1 \\
5 \\
1\end{array}$ & $\begin{array}{l}0 . \\
6 \\
4\end{array}$ & $\begin{array}{l}0 . \\
3 \\
5\end{array}$ & $\begin{array}{l}70 \\
.1 \\
0\end{array}$ & $\begin{array}{l}0 . \\
03 \\
7\end{array}$ & $\begin{array}{l}0.0 \\
06 \\
0\end{array}$ & $\begin{array}{l}0 . \\
0 \\
1 \\
1\end{array}$ & $\begin{array}{l}0 . \\
0 \\
1 \\
2\end{array}$ & $\begin{array}{l}0 \\
5 \\
4\end{array}$ \\
\hline $\begin{array}{l}\text { It } \\
\text { e } \\
\text { m } \\
- \\
3\end{array}$ & $\begin{array}{l}1 . \\
4 \\
2\end{array}$ & $\begin{array}{l}2 . \\
8 \\
5\end{array}$ & $\begin{array}{l}4 \\
5 \\
4\end{array}$ & $\begin{array}{l}1 \\
5 \\
5\end{array}$ & $\begin{array}{l}0 . \\
6 \\
4\end{array}$ & $\begin{array}{l}0 . \\
3 \\
1\end{array}$ & $\begin{array}{l}70 \\
.1 \\
2\end{array}$ & $\begin{array}{l}0 . \\
03 \\
5\end{array}$ & $\begin{array}{l}0.0 \\
07 \\
0\end{array}$ & $\begin{array}{l}0 . \\
0 \\
1 \\
0\end{array}$ & $\begin{array}{l}0 . \\
0 \\
1 \\
1\end{array}$ & $\begin{array}{l}0 \\
. \\
9 \\
5\end{array}$ \\
\hline $\begin{array}{l}\text { Ite } \\
\mathrm{m} \\
4\end{array}$ & $\begin{array}{l}1 . \\
4 \\
5\end{array}$ & $\begin{array}{l}2 . \\
8 \\
0\end{array}$ & $\begin{array}{l}4 \\
5 \\
3\end{array}$ & $\begin{array}{l}1 \\
5 \\
6\end{array}$ & $\begin{array}{l}0 . \\
6 \\
7\end{array}$ & $\begin{array}{l}0 . \\
3 \\
2\end{array}$ & $\begin{array}{l}70 \\
.1 \\
3\end{array}$ & $\begin{array}{l}0 . \\
03 \\
6\end{array}$ & $\begin{array}{l}0.0 \\
05 \\
8\end{array}$ & $\begin{array}{l}0 . \\
0 \\
1 \\
2\end{array}$ & $\begin{array}{l}0 . \\
0 \\
1 \\
3\end{array}$ & $\begin{array}{l}0 \\
5 \\
5 \\
6\end{array}$ \\
\hline
\end{tabular}


Table-2b: Parametric values

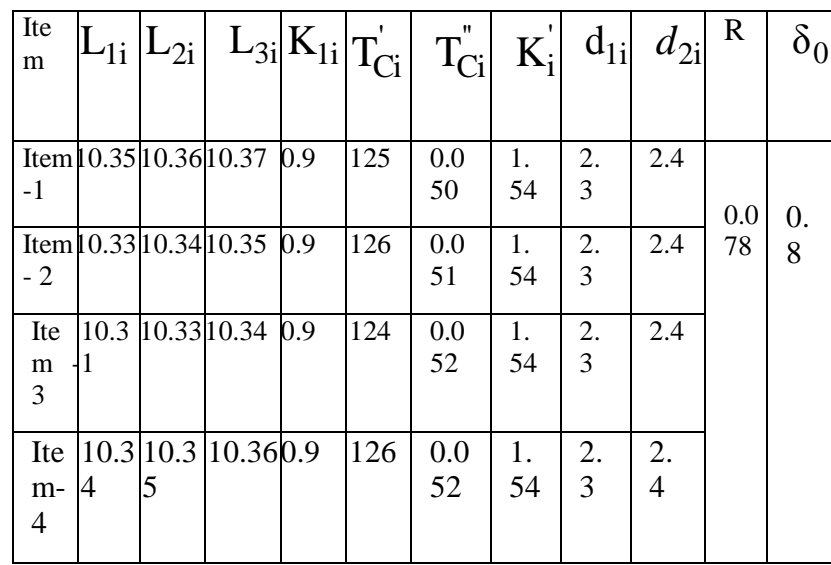

Table-3: Optimal Result for $\mathbf{y}=\mathbf{0 . 5}$

\begin{tabular}{|l|l|l|l|}
\hline & Scenario-I & Scenario-II & Scenario-III \\
\hline PROF & 98845.31 & 90626.43 & 81107.82 \\
\hline $\mathrm{S}_{1}$ & 225.14 & 95.36 & 89.78 \\
\hline $\mathrm{S}_{2}$ & 59.80 & 149.84 & 317.70 \\
\hline $\mathrm{S}_{3}$ & 74.93 & 45.99 & 27.75 \\
\hline $\mathrm{S}_{4}$ & 121.67 & 41.77 & 70.79 \\
\hline $\mathrm{W}_{1}$ & 2.00 & 35.87 & 6.67 \\
\hline $\mathrm{W}_{2}$ & 14.99 & 3.55 & 44.22 \\
\hline $\mathrm{W}_{3}$ & 11.87 & 24.13 & 1.07 \\
\hline $\mathrm{W}_{4}$ & 39.21 & 9.64 & 20.89 \\
\hline $\mathrm{W}_{1}{ }^{\prime}$ & 36.36 & 35.87 & 0.55 \\
\hline $\mathrm{W}_{2}{ }^{\prime}$ & 33.82 & 3.55 & 38.29 \\
\hline $\mathrm{W}_{3}{ }^{\prime}$ & 25.37 & 24.13 & 0.35 \\
\hline $\mathrm{W}_{4}{ }^{\prime}$ & 52.16 & 9.64 & 14.02 \\
\hline $\mathrm{t}_{11}$ & 2.1802 & 0.6267 & 1.0548 \\
\hline $\mathrm{t}_{12}$ & 0.0 .2917 & 1.6767 & 2.6407 \\
\hline $\mathrm{t}_{13}$ & 0.5405 & 0.2308 & 0.3187 \\
\hline $\mathrm{t}_{14}$ & 0.6948 & 0.3648 & 0.6144 \\
\hline $\mathrm{t}_{21}$ & 2.5823 & 0.6267 & 0.9813 \\
\hline & 0.5035 & 1.6767 & 2.5833 \\
\hline & 0.6882 & 0.2308 & 0.3067 \\
\hline & & & \\
\hline & & & \\
\hline & & & \\
\hline & & & \\
\hline & & & \\
\hline & & & \\
\hline & & & \\
\hline & & & \\
\hline & & & \\
\hline & & & \\
\hline
\end{tabular}

\begin{tabular}{|l|l|l|l|}
\hline $\mathrm{t}_{32}$ & 0.6780 & 1.7181 & 3.0433 \\
\hline $\mathrm{t}_{33}$ & 0.8210 & 0.4967 & 0.3191 \\
\hline $\mathrm{t}_{34}$ & 1.2475 & 0.4766 & 0.7744 \\
\hline
\end{tabular}

Table-4: Effect on profit for different values of $y$

\begin{tabular}{|l|l|l|l|l|l|}
\hline Scenario & $\mathrm{Y}=0.0$ & $\mathrm{Y}=0.25$ & $\mathrm{Y}=0.5$ & $\mathrm{Y}=0.75$ & $\mathrm{Y}=1.0$ \\
\hline I & 98716.62 & 98787.01 & 98845.31 & 98903.55 & 98961.79 \\
\hline II & 90516.89 & 90571.66 & 90626.43 & 90681.14 & 90735.90 \\
\hline III & 81014.16 & 81060.82 & 81107.81 & 81154.16 & 81200.63 \\
\hline
\end{tabular}

\section{DISCUSSION}

For the input data's (given in Table-2a and $-2 b$ ), optimal results in Table- 3 for particular value of $y=0.5$ shows that the maximum profit value occurs corresponding to Scenario-I. The optimal results in Table- 4 shows that the profit value increases as the value of $y$ increases and for all these values of $\mathrm{y}$, Scenario-I gives the better result than other scenarios.

\section{CONCLUSION}

In this paper, we consider one Primary Warehouse, $\mathrm{m}$ secondary warehouses and $\mathrm{N}$ items. The warehouses SW1, $\mathrm{SW} 2, \ldots, \mathrm{SWm}$ contains $\mathrm{N} 1, \mathrm{~N} 2, \ldots, \mathrm{Nm}$ items respectively such that $\mathrm{N} 1+\mathrm{N} 2+\ldots+\mathrm{Nm}=\mathrm{N}$. Items are sold from PW which is located at the market place and shortages are allowed at this shop. Due to large stock and insufficient space of existing $\mathrm{PW}$, excess items are stored in $\mathrm{m}$ secondarywarehouses (viz., $\mathrm{SW} 1, \mathrm{SW} 2, \ldots . ., \mathrm{SWm}$ ) of finite capacity which are little away from PW. Here all the warehouses are of rental basis but rent of PW is greater than the rent of the secondary warehouses as they (SWs) are in little away from market place. Deterioration rate of an item is taken to be different in different warehouses. As the demand of an item is stock dependent, attempt is made to keep the showroom (PW) full bringing the items from SWs at the earliest though the rent at SWs are less than that at PW. Hence the stocks of SWs are transferred to PW under continuous release pattern and the associated transportation cost is directly varies with the distance from PW to SWs but the holding cost of an item in SWs has reverse effect with distance.. The backlogged demand is assumed to be a function of currently backlogged amount. Here, the problem is developed with fuzzy lead-time under inflation and time value of money. The fuzzy parameter is transformed into a crisp number by Graded Mean Integration Value (GMIV) method. There are three scenarios in each cycle depending upon the time when new order is placed. The present analysis can be applied for seasonable / fashionable goods which are marketed for a fixed time period. A soft computing method i.e., genetic algorithm for inventory control problems have been developed in most general way and this can be used to solve other single-objective inventory models in different environments. 


\section{REFERENCES}

[1] R.V. Hartely (1976), Operation Research- A managerial Emphasis, Good Year Publishing Company, California, 315-317.

[2] K. V. S. Sarma (1983), A deterministic order-level inventory model for deteriorating items with two storage facilities, European Journal of Operational Research, 29, 70-72.

[3] A. Goswami and K.S. Chaudhuri (1992), An economic order quantity model for items with two level of storage of levels for linear trend in demand, Journal of Operational Research Society, 43, 1173-78.

[4] T.P.M Pakkala and K.K Achary (1992a), A deterministic inventory model for deteriorating items with two warehouses and finite replenishment rate, European Journal of Operational Research, 57, 71-76.

[5] T.P.M Pakkala and K.K Achary (1992b), Discrete time inventory model for deteriorating items with two warehouses, Opsearch, 29, 90-103.

[6] A.K Bhunia and M. Maiti (1998), A two warehouses inventory model for deteriorating items with a linear trend in demand and shortages, Journal of Operational Research Society, 49, 289-292.

[7] I. R. Levin, C.P. Mclaughlin, P. R. Lamone and J. F. Kottas (1972), Production/operations management contemporary policy for managing operating systems. McGraw-Hill, New York.

[8] A. E Silver and R. Peterson (1985), Decision system of inventory management and research, John Wiley, New York.

[9] R. C. Baker and T.L. Urban (1988), A deterministic inventory system with an inventory level dependent demand rate,, Journal of Operational Research Society, 39,1823-1831.

[10] B. N. Mandal and S. phausder (1998), An inventory model for deteriorating items and stock dependent consumption rate, , Journal of Operational Research Society, 40, 483-488.

[11] T.K. Datta and A. K. Pal (1990), A note on an inventory model with inventory level dependent demand rate, Journal of Operational Research Society, 41, 971-975.

[12] T.K. Datta and A. K. Pal (1990), Deterministic inventory system for deteriorating items with inventory level dependent demand rate and shortages, Opsearch, 27, 213-224.

[13] S. H. Chen and C. H. Hsieh (1999), Graded Mean integration representation of generalized fuzzy numbers, Journal of Chinese Fuzzy systems 5(2), 1-7.

[14] J. C. Pan and Y. C. Hsiao (2001), Inventory models with backorder discounts and variable leadtime, International Journal of system Science, 32, 925-929.

[15] J. C. Pan and Y. C. Hsiao (2005), Integrated inventory models with controllable lead-time and backorder discount considerations, International Journal of Production of Economics, 93-94, 387- 397.

[16] J.A. Buzacott (1975), Economic order quantities with inflation, Operational Research Quarterly, 26(3) , 553558. 17. R.B. Misra (1979), A note on optimal inventory management under inflation, Naval Research Logistics, 26 1D, 161-165.

[17] J. Ray and K.S. Chaudhuri (1997), An EOQ model with stock-dependent demand, shortage, inflation and time discounting, Inter. Journal of Production Economics, 53, 171-180. 